\title{
Towards a Theory of Stakeholders' Perception of Tourism Impacts
}

\author{
Martin Luštický, Martin Musil \\ e-mail: martin.lusticky@vse.cz / musi|@fm.vse.cz
}

Department of Management, Faculty of Management, University of Economics, Prague, Czech Republic

Luštický, M., \& Musil, M. (2016). Towards a Theory of Stakeholders' Perception of Tourism Impacts. Czech Journal of Tourism, 5(2), 93-110. DOI: 10.1515/cjot-2016-0006.

\begin{abstract}
This paper summarizes theoretical knowledge related to an issue of assessment of tourism impacts on a tourism destination. This paper pays special attention to stakeholders' perception of tourism impacts as a popular approach to tourism impacts assessment in recent decades. Its aim is to map the key research focused on classification and assessment of tourism impacts in relation to regional stakeholders, using a summary and comparison of various research approaches over the past decades. The paper uses an integrative literature review of 28 papers published in top-rated journals which can be considered as a relevant sample of the research effort from the beginnings of 1990s. It compares commonly used approaches to the classification and assessment of tourism impacts through a comparative content analysis and points out their common characteristics and differences. The secondary aim is to define research implications as a theoretical and methodical basis for future research aimed at this topic.
\end{abstract}

\section{Keywords}

Tourism, tourism impact, stakeholder, tourism destination, assessment

JEL classification: Z30, Z32, R58 


\section{Introduction}

Research effort related to the tourism impacts assessment has significantly grown during the past three decades. The pioneer studies concerning mainly the economic effects of tourism can be found in the 1960s and 1970s. Matheison and Wall (1982) presented in their book a summary of research findings up to that time and classified the impacts into three categories: (a) economic, (b) physical, and (c) social. Ritchie (1984) elaborated this classification and grouped tourism impacts into four categories: (a) physical/environmental, (b) social/cultural, (c) psychological and (d) political/administrative.

Nowadays, there is a common agreement on three broad categories of tourism impacts - (a) economic, (b) socio-cultural and (c) environmental. Despite this fact, specific research designs to their examination significantly differ. As Stylidis, Biran, Sit, and Szivas (2014) note, it is possible to distinguish these main approaches to the examination of tourism impacts:

- The cost-benefit approach - the most prevalent approach focused on costs and benefits of tourism, or more precisely, on positive and negative impacts of tourism; the approach assumes a direct negative relationship between the stakeholders' support for tourism development and the perceived costs, and vice versa, a direct positive relationship between the perceived benefits and the stakeholders' support;

- The domain related to the costs-benefits approach - this approach provides a more comprehensive analysis of tourism impacts, taking into consideration both the nature (positive/negative or cost/benefit) and domain (economic, socio-cultural, environmental) of impacts; the approach assumes the same relationship between the stakeholders' support for tourism development and the perceived (economic, sociocultural, environmental) costs / benefits as the cost-benefit approach does;

- The non-forced approach - a popular approach, which focuses on the relationship between the perceived impacts and the support for tourism development by asking stakeholders for their perceptions of the extent to which they consider tourism to have a positive or negative impact on community life; the approach assumes a dependency between the extent of stakeholders' perception of tourism impacts and their willingness to support the tourism development.

The non-forced or stakeholder approach has been gaining increasing attention in the tourism literature in recent three decades. This approach is closely related to the concept of sustainable tourism development. Tourism is seen as a means to sustain the use of natural resources, social and cultural development of a local community, and provide income and economic security for a destination and its stakeholders. However, tourism has the potential to create both positive and negative impacts. That is why a number of authors (e.g., Yuksel, Bramwell, \& Yuksel, 1999; Ritchie \& Crouch, 2003; Hall, 2008; Goeldner \& Ritchie, 2012; Morrison, 2013) point out that tourism development must be planned and responsibly managed in such a way so that it could generate positive impacts for destination stakeholders. 
As Byrd and Gustke (2004) state that a perceived impact is one of the main predictors for the stakeholders' support for sustainable tourism development in their community. Therefore, understanding the stakeholders' perception towards tourism impacts, their attitude, interests and overall willingness to support the tourism development is considered to be the key to the sustainable development of tourism in a destination (Byrd, Bosley, \& Dronberger, 2009). Kuvan and Akan (2012, p. 572) suggest that the process of "identifying the perceptions and attitudes of various stakeholders toward tourism development in a community should be taken as a first step in tourism planning in order to ensure trust, cooperation, harmony and mutual benefit for all those involved." Likewise, Gursoy and Rutherford (2004, p. 495) note that understanding of the roots of stakeholders' attitude to the tourism development is a crucial piece of knowledge for government planners and policymakers because "the success and sustainability of any development depends on active support of the local populations". That is why many researchers have examined stakeholders' perceptions of tourism impacts on their communities in hope of better understanding (e.g., Byrd, Bosley, \& Dronberger, 2009; Brida, Osti, \& Faccioli, 2011; Stylidis et al., 2014; Sinclair-Maragh, Gursoy, \& Vieregge, 2015).

This paper summarizes theoretical knowledge related to the topic of stakeholders' perception of tourism impacts on a tourism destination. Its aim is to map the key research focused on classification and assessment of tourism impacts in relation to regional stakeholders. The core of the paper consists of an integrative review of 28 papers from toprated journals (e.g., Annals of Tourism Research, Tourism Management, and Journal of Sustainable Tourism) which can be considered as a relevant sample of the research effort over the past decades. In a comprehensive form, the paper presents commonly used approaches to the classification and assessment of tourism impacts. It compares these approaches through a comparative content analysis and points out their common characteristics and differences.

In this way the paper contributes to building a theoretical and methodological basis for any research focused on the topic of stakeholders' perception of tourism impacts by providing up-to-date information. The paper also defines research implications and possible limitations which should be significant for any future research effort.

\section{Literature Review}

\section{Economic Impacts of Tourism}

The empirical research analysing the relationship between the tourism activity and the economic growth has been flourishing since 1970s. The travel and tourism sector is widely recognized as an important factor for the regional development which has a potential to contribute to the development of national and regional economies (e.g., Alavi \& Yasin, 2000; Kozak, 2004; Edgell, DelMastro Allen, Smith, \& Swanson, 2008). Many authors (e.g., Sharma, 2004; Dwyer, Forsyth, \& Dwyer, 2010; Vanhove, 2011) have highlighted the potential of the tourism sector in promoting the economic growth. It contributes to the stability of economies, especially because of its multiplier effect launched by travellers' 
expenses. The multiplier has a positive effect on the creation of various entrepreneurial opportunities and thus, it affects the employment rate in a given region (Dwyer, Forsyth, \& Dwyer, 2010).

It is possible to identify some of the most frequently mentioned economic impacts that tourism can, either directly or indirectly, generate in the region: employment opportunities, income growth, development of small and medium business, government revenue, support for new investments, reducing regional disparities, increase value of land and realty, changes in the quantity and quality of goods and services (e.g., Zhou, Yanagida, Chakravorty, \& Leung, 1997; Cooper, Fletcher, Fyall, Gilbert, \& Wanhill, 2008; Hall, 2008; Sharma, Dyer, Carter, \& Gursoy, 2008; Jaafar, Kayat, Tangit, \& Yacob, 2013; Simão \& Môsso, 2013; Pratt, 2015). The most studies view the economic impact of tourism in a positive way as an opportunity for the economic growth and resulting development of a particular area (e.g., Cooper et al., 2008; Backman, Hsu, \& Backman, 2011; Sinclair-Maragh, Gursoy, \& Vieregge, 2015). Nevertheless, many authors examine or mention the economic costs and negative effects associated with the tourism development, such as a crowding out effect, seasonality of jobs, lower wages in the tourism sector, inappropriate investments for the local environment, or a possibility of increasing inflation (e.g., Zhou et al., 1997; Cooper et al., 2008; Hall, 2008; Zhong, Deng, Song, \& Ding, 2011; Jaafar et al., 2013; Pratt, 2015). Similarly, the authors also point to the fact that different types of tourism can lead to different impacts or their intensity.

The economic benefits of tourism are mostly measured by the following methods using data from the Tourism Satellite Account or official documents / government agencies for estimating the regional economic impacts of tourism: the input-output (I/O) analysis (e.g., Zhou et al., 1997), calculation of tourism multiplier effect (e.g., Steenge \& Van de Steeg, 2010), CGE model (e.g., Pratt, 2015), or Social Accounting Matrix (e.g., Wagner, 1997). Visitor monitoring and interviews are also often used as data gathering methods needed for the travel cost method (e.g., Mugambi \& Mburu, 2013). All of these techniques have its limitation, especially on the local level where the main problem is connected with valid data availability.

\section{Socio-Cultural and Environmental Impacts of Tourism}

While the economic impacts of tourism receive the main emphasis and analysis, there is also a growing interest among researchers in analyzing tourism sector as a factor of cultural, social and environmental changes in a tourist destination. It is recognized that economic impacts are linked to, and cannot easily be separated from other types of impact (Mason, 2008; Kuvan \& Akan, 2012).

Teo (1994, p. 126) defines social and cultural impacts as "the ways in which tourism is contributing to change in the value systems, morals and their conduct, individual behavior, family relationships, collective lifestyles, creative expressions, traditional ceremonies and community organizations". As Teo (1994) noted, the quintessence of the impacts lay in the effects on the host community as a result of direct or indirect association with 
tourists. From this point of view, tourism is seen as a sector that can provide a high impact, especially on local communities (Jaafar et al., 2013; Pratt, 2015).

The social impacts of tourism refer to changes in the lives of people living in destination communities. They usually involve more immediate changes in the life quality. The cultural impacts are those which lead to a longer-term, gradual change in a society's values, beliefs, cultural practices, customs, rituals, arts, artifacts, and architecture of host communities. They appear as long-term changes (Teo, 1994; Haralambopoulos \& Pizam, 1996; Brunt \& Courtney, 1999; Backman, Hsu, \& Backman, 2011; Stylidis et al., 2014). It is possible to highlight these most frequently mentioned socio-cultural impacts: higher standard of living, community's appearance, higher quality of public services, improvement of the roads and public facilities, development of cultural activities, recreational opportunities, restoration of historical buildings, cultural exchange, cultural identity, preservation of local culture (e.g., Gursoy \& Rutherford, 2004; Sharma et al., 2008; Byrd, Bosley, \& Dronberger, 2009; Kuvan \& Akan, 2012). On the contrary, the authors usually mention these negative impacts: higher crime rate, vandalism, prostitution, gambling, traffic congestion, restriction in using recreational facilities, loss of traditions, overcrowded town centers, disruption of everyday life (Gursoy \& Rutherford, 2004; Sharma et al., 2008; Byrd, Bosley, \& Dronberger, 2009; Kuvan \& Akan, 2012; Rio \& Nunes, 2012; Xie, Bao, \& Kerstetter, 2014).

The third important category of tourism impacts is the environmental sphere. The quality of environment in a destination is essential to sustainable tourism development. However, the relationship between tourism and destination environment is quite complex; many developing activities can have adverse environmental effects. The negative impacts of tourism development can gradually destroy the environmental resources and in this way erode the tourism development in a long-term horizon (Hall, 2008; Mason, 2008; Jaafar et al., 2013; Newsome, Moore, \& Dowling, 2013; Pásková, 2014).

The interaction between the tourism development and the environmental change is a matter of interest of many authors. They try to classify and examine mainly the negative impact of tourism to destination environment such as air and water pollution, undesirable changes in natural processes, increasing waste production, increasing consumption of natural resources, disproportionate land use, devaluation of natural beauty, or interventions into the life of animals (Wall \& Mathieson, 2005; Cooper et al., 2008; Hall, 2008; Mason, 2008; Zhong et al., 2011; Kuvan \& Akan, 2012; Newsome, Moore, \& Dowling, 2013; Pásková, 2014). However, some of the tourism impacts are considered to be positive: emergence of nature reservations and open-air museums, protection of nature heritage, development of environmentally friendly facilities, conservation of natural resources, higher participation in resource management, residents' environmental awareness (Hall, 2008; Mason, 2008; Rio \& Nunes, 2012; Newsome, Moore, \& Dowling, 2013; Pásková, 2014; Pomucz \& Csete, 2015).

The essence of socio-cultural and environmental impacts causes the authors some difficulties in their effort to examine them. The most common data gathering method is a survey among stakeholders. The data are used as inputs into various methods such as Doxey's irridex, Butler's model of tourism development (Teo, 1994), Framework method 
(Brunt \& Courtney, 1999), qualitative content analysis (Jaafar et al., 2013), or statistical methods like ANOVA test, t-test, Levene test, frequency analysis, factor analyses (e.g., Sharma et al., 2008; Prayag, Dookhony-Ramphul, \& Maryeven, 2010; Kuvan \& Akan, 2012). Monitoring and evaluation of socio-cultural and environmental impacts is closely connected with sustainable tourism development. Thus, the system of relevant indicators is also often mentioned and used as a tool for monitoring and prevention of the negative impacts (Rio \& Nunes, 2012; Newsome, Moore, \& Dowling, 2013; Pásková, 2014).

\section{Stakeholders' Perception of Tourism Impacts}

As the previous text clearly indicates, tourism has multiple impacts on nations / regions in the economic, socio-cultural and environmental spheres. The national or regional governments are aware of tourism potential and thus, they try to formulate a specific tourism policy to be able to influence the tourism development and maximize its positive impacts on a given territory. The governments usually establish nonprofit agencies in the form of purpose-designed tourism bodies or destination management organisations (DMOs), the main purpose of which is to implement tourism policy goals and manage tourism in such a way to be beneficial for all main destination stakeholders (Page, 2013).

However, managing tourism in accordance with the stakeholders' interests is a difficult and challenging task (Buhalis, 2000). Aas, Ladkin, and Fletcher (2005) summarize a number of challenges such as increased costs of management processes, difficult identification of legitimate stakeholders and their view on the tourism development in a destination, and the stakeholders' limited capacity to participate in the tourism development. In addition, tourism is an open, multi-dimensional industry with a fragmented nature. Quite a lot of stakeholders with various interests, complex mutual relations and different willingness to co-operate can be found in a given destination.

The term stakeholder was defined by Freeman who considered a stakeholder as "any group or individual who can affect or is affected by the achievement of the organization's objectives" (Freeman, 1984, p. 46). This classical definition has been modified many times; dozens of various definitions in the literature can be found. The tourism \& hospitality sector is not an exception. Although stakeholders are subject of interest of many authors, there is no universal definition of this term. The following table summarizes different approaches to stakeholder's definition over the past two decades.

Table 1 Definitions of the term "stakeholder"

\begin{tabular}{|l|l|}
\hline Author(s) & Stakeholder definition \\
\hline Savage et al. (1991, p. 61) & $\begin{array}{l}\text { "have an interest in the actions of an organization and the ability to } \\
\text { influence it" }\end{array}$ \\
\hline Nutt and Backoff (1992, p. 439) & "all parties who will be affected by or will affect strategy" \\
\hline
\end{tabular}




\begin{tabular}{|l|l|}
\hline Author(s) & Stakeholder definition \\
\hline Caroll (1993, p. 22) & $\begin{array}{l}\text { "individuals or groups with which business interacts who have a stake } \\
\text { or vested interest in the firm" }\end{array}$ \\
\hline Wicks et al. (1994, p. 483) & "interact with and give meaning and definition to the corporation" \\
\hline Clarkson (1995, p. 106) & $\begin{array}{l}\text { "have, or claim, ownership, rights, or interests in a corporation and its } \\
\text { activities" }\end{array}$ \\
\hline Bryson (1995, p. 27) & $\begin{array}{l}\text { "any person, group or organization that can place a claim on the } \\
\text { organization's attention, resources, or output, or is affected by that } \\
\text { output" }\end{array}$ \\
\hline $\begin{array}{l}\text { Gray, Owen and Adams } \\
\text { (1996, p. 45) }\end{array}$ & $\begin{array}{l}\text { "any human agency that can be influenced by, or can itself influence, } \\
\text { the activities of the organization in question" }\end{array}$ \\
\hline $\begin{array}{l}\text { Eden and Ackermann } \\
\text { (1998, p. 117) }\end{array}$ & $\begin{array}{l}\text { "people or small groups with the power to respond to, negotiate with, } \\
\text { and change the strategic future of the organization" }\end{array}$ \\
\hline Gibson (2000, p. 245) & $\begin{array}{l}\text { "those groups or individuals with whom the organization interacts or } \\
\text { has interdependencies and any individual or group who can affect or is } \\
\text { affected by the actions, decisions, policies, practices, or goals of the } \\
\text { organization }\end{array}$ \\
\hline Lampe (2001, p. 166) & "parties affected by an organization" \\
\hline $\begin{array}{l}\text { Johnson and Scholes } \\
\text { (2002, p. 206) }\end{array}$ & $\begin{array}{l}\text { "those individuals or groups who depend on the organization to fulfill } \\
\text { their own goals and on whom, in turn, the organization depends" }\end{array}$ \\
\hline Phillips (2003, p. 30) & $\begin{array}{l}\text { "normative stakeholders: for whose benefits should the firm be } \\
\text { managed" } \\
\text { "derivative stakeholders: potential to affect organization and its } \\
\text { normative stakeholders" }\end{array}$ \\
\hline
\end{tabular}

Source: Mitchell, Agle, and Wood (1997), Bryson (2004), Friedman and Miles (2006)

From the point of view of destination management, the destination stakeholders can be widely defined as such organizations which are affected by the destination management or which are able to affect its success. Presenza, Sheehan, and Ritchie (2005, p. 9) used a more precise definition; they defined stakeholders as "any entity that is influenced by, or that may influence, the achievement of the destination management activities".

It is possible to find another two terms used within the context of the stakeholder theory: "actor" and "agent". The term "actor" has no such precise methodological basis when comparing with the term "stakeholder". Generally speaking, an actor is able to act and decide independently and individually. This term usually refers to any entity involved in tourism industry no matter how its stake is significant. It is usually used within a connection to social environment of a destination when trying to find mutual links between the actors based on the Actor-Network Theory (e.g., Jóhannesson, 2005; Paget, Dimanche, \& Mounet, 2010; Colarič-Jakše, 2015). However, some authors use this term as an equivalent to the term "stakeholder". Saxena (2014, p. 488), for example, defines actors as "those who have a stake in tourism planning, promotion and development such as policy makers, businesses, non-profit making sector and community groups". 
The term "agent" has been mostly used as a technical term from the sphere of systemdynamic models which are able to describe behavior of complicated and complex systems. In economic sciences this term refers to an actor and decision-maker in economic models. In travel \& tourism industry the agents represent destination stakeholders / actors, i.e., the real units occurring in a destination such as residents, visitors, tourist organizations, and local government which act and react in the context of defined environment. Although there is no universal definition of the agents, we can describe them as active elements of a system which have been made by human for specific purpose like examination of their behavior, mutual relations and impact on a system (Musil \& Luštický, 2010).

The main purpose of examining destination stakeholders is their importance for successful implementation of tourism policy and managing tourism development. Gunn (1994), Buhalis (2000), Gursoy and Rutherford (2004), and Hall (2008) argue that the success of these activities is dependent on the support of the key destination stakeholders, which is considered by some authors (e.g., Ritchie \& Crouch, 2003; Byrd, Cardénas, \& Greenwood, 2008) as an important factor of destination competitiveness or a factor contributing to the sustainable tourism development (e.g., Byrd, Bosley, \& Dronberger, 2009; Waligo, Clarke, \& Hawkins, 2013). Sharma and Dyer (2009) emphasize the fact that the stakeholders' support of tourism policy depends on their attitudes toward tourism impacts on economic, social, cultural and environmental environment of a given destination.

\section{Comparative Content Analysis}

This part describes a comparative content analysis of 28 papers published in international journals in the field of tourism \& hospitality sector. The papers were selected according to the following criteria: (a) publication date between 1990- 2015, (b) publication in peer review journal, (c) orientation on tourism impacts and their perception by destination stakeholders, (d) clearly described application area of the research, (e) clearly described methodology / methods used for the research. These papers represent a sample of the research effort during last three decades and map its common characteristics, differences, and limitations.

The Table 2 includes the most important characteristics of the selected papers such as (a) author(s) identification, (b) scope of the paper - tourism impacts, (c) application area, (d) data - (d1) data source, (d2) data collection method, (d3) data analysis method. 
Table 2 Comparison of the most important characteristics of the selected papers

\begin{tabular}{|c|c|c|c|}
\hline Author(s) & Tourism impacts & Application area & Data \\
\hline $\begin{array}{l}\text { Lankford and } \\
\text { Howard (1994) }\end{array}$ & $\begin{array}{l}\text { economic, social, } \\
\text { environmental }\end{array}$ & $\begin{array}{l}\text { national scenic } \\
\text { area, Oregon, USA }\end{array}$ & $\begin{array}{l}\text { D1: residents } \\
\text { D2: self-administered questionnaires (Likert } \\
\quad \text { scale) } \\
\text { D3: tourism impact attitude scale (TIAS) }\end{array}$ \\
\hline Teo (1994) & socio-cultural & city / state & $\begin{array}{l}\text { D1: tourism development plan; residents } \\
\text { D2: content analysis; interviews (Likert scale) } \\
\text { D3: Doxey's irridex, Butler's model of tourism } \\
\text { development }\end{array}$ \\
\hline $\begin{array}{l}\text { Haralambopoulos } \\
\text { and Pizam (1996) }\end{array}$ & economic, social & $\begin{array}{l}\text { city, Samos Island, } \\
\text { Greece }\end{array}$ & $\begin{array}{l}\text { D1: residents } \\
\text { D2: face-to-face interviews (Likert scale) } \\
\text { D3: mean and standard deviation, Pearson } \\
\quad \text { correlation }\end{array}$ \\
\hline $\begin{array}{l}\text { Brunt and } \\
\text { Courtney (1999) }\end{array}$ & socio-cultural & $\begin{array}{l}\text { seaside resort, } \\
\text { United Kingdom }\end{array}$ & $\begin{array}{l}\text { D1: residents } \\
\text { D2: structured interviews (open-ended } \\
\quad \text { questions) } \\
\text { D3: framework method (familiarization, } \\
\quad \text { identifying a thematic framework, } \\
\text { indexing, charting, and mapping and } \\
\text { interpretation) }\end{array}$ \\
\hline $\begin{array}{l}\text { Besculides, Lee } \\
\text { and McCormick } \\
\text { (2002) }\end{array}$ & cultural & $\begin{array}{l}\text { scenic byway, } \\
\text { Colorado, USA }\end{array}$ & $\begin{array}{l}\text { D1: residents } \\
\text { D2: self-administered questionnaires (Likert } \\
\quad \text { scale) } \\
\text { D3: arithmetic mean }\end{array}$ \\
\hline $\begin{array}{l}\text { Gursoy, Jurowski } \\
\text { and Uysal (2002) }\end{array}$ & $\begin{array}{l}\text { economic, } \\
\text { socio-cultural, } \\
\text { environmental }\end{array}$ & $\begin{array}{l}\text { county, Virginia, } \\
\text { USA }\end{array}$ & $\begin{array}{l}\text { D1: residents } \\
\text { D2: self-administered questionnaires (Likert } \\
\text { scale) } \\
\text { D3: maximum likelihood method of estimation } \\
\text { (LISREL } 8 \text { structural equation analysis } \\
\text { package) }\end{array}$ \\
\hline $\begin{array}{l}\text { Gursoy and } \\
\text { Rutherford (2004) }\end{array}$ & $\begin{array}{l}\text { economic, socio- } \\
\text { cultural }\end{array}$ & $\begin{array}{l}\text { counties, } \\
\text { Washington, Idaho, } \\
\text { USA }\end{array}$ & $\begin{array}{l}\text { D1: residents } \\
\text { D2: self-administered questionnaires (Likert } \\
\text { scale) } \\
\text { D3: chi-square statistics, the goodness-of- } \\
\text { fit index (GFI), the non-normed-fit index } \\
\text { (NNFI), the comparative fit index (CFI), } \\
\text { the incremental Fit Index (IFI), the critical } \\
\text { N statistic }\end{array}$ \\
\hline $\begin{array}{l}\text { Andereck, } \\
\text { Valentine, Knopf } \\
\text { and Vogt (2005) }\end{array}$ & $\begin{array}{l}\text { economic, } \\
\text { socio-cultural, } \\
\text { environmental }\end{array}$ & $\begin{array}{l}\text { county, Arizona, } \\
\text { USA }\end{array}$ & $\begin{array}{l}\text { D1: residents } \\
\text { D2: self-administered questionnaires (Likert } \\
\quad \text { scale) } \\
\text { D3: factor analysis, MANOVA models }\end{array}$ \\
\hline $\begin{array}{l}\text { Haley, Snaith and } \\
\text { Miller (2005) }\end{array}$ & social & $\begin{array}{l}\text { city, United } \\
\text { Kingdom }\end{array}$ & $\begin{array}{l}\text { D1: residents } \\
\text { D2: self-administered questionnaires (Likert } \\
\quad \text { scale) } \\
\text { D3: factor and regression analyses }\end{array}$ \\
\hline
\end{tabular}




\begin{tabular}{|c|c|c|c|}
\hline Author(s) & Tourism impacts & Application area & Data \\
\hline $\begin{array}{l}\text { Lu, Wu and Xiao } \\
(2006)\end{array}$ & $\begin{array}{l}\text { economic, } \\
\text { socio-cultural, } \\
\text { environmental }\end{array}$ & $\begin{array}{l}\text { national park, } \\
\text { China }\end{array}$ & $\begin{array}{l}\text { D1: residents, tourism managers, tourists } \\
\text { D2: interviews (Likert scale) } \\
\text { D3: Fuzzy Synthetic Evaluation }\end{array}$ \\
\hline $\begin{array}{l}\text { Dyer, Gursoy, } \\
\text { Sharma and } \\
\text { Carter (2007) }\end{array}$ & $\begin{array}{l}\text { economic, } \\
\text { socio-cultural, } \\
\text { environmental }\end{array}$ & $\begin{array}{l}\text { seaside resort, } \\
\text { Queensland, } \\
\text { Australia }\end{array}$ & $\begin{array}{l}\text { D1: residents } \\
\text { D2: self-administered questionnaires (Likert } \\
\text { scale) } \\
\text { D3: Exploratory Factor Analysis, Confirmatory } \\
\text { Factor Analysis }\end{array}$ \\
\hline $\begin{array}{l}\text { Sharma, Dyer, } \\
\text { Carter and } \\
\text { Gursoy (2008) }\end{array}$ & social & $\begin{array}{l}\text { seaside resort, } \\
\text { Queensland, } \\
\text { Australia }\end{array}$ & $\begin{array}{l}\text { D1: residents } \\
\text { D2: self-administered questionnaires (Likert } \\
\quad \text { scale) } \\
\text { D3: correlation analysis, frequency analysis }\end{array}$ \\
\hline $\begin{array}{l}\text { Bruyere, Beh and } \\
\text { Lelengula (2009) }\end{array}$ & economic & rural region, Kenya & $\begin{array}{l}\text { D1: protected area leadership and staff, } \\
\text { residents } \\
\text { D2: semi-structured interviews (open-ended } \\
\text { questions) } \\
\text { D3: three-step coding method for qualitative } \\
\quad \text { content analysis }\end{array}$ \\
\hline $\begin{array}{l}\text { Byrd, Bosley and } \\
\text { Dronberger (2009) }\end{array}$ & $\begin{array}{l}\text { economic, socio- } \\
\text { cultural }\end{array}$ & $\begin{array}{l}\text { county, North } \\
\text { Carolina, USA }\end{array}$ & $\begin{array}{l}\text { D1: entrepreneurs, government officials, } \\
\text { residents, tourists } \\
\text { D2: self-administered questionnaires (Likert } \\
\text { scale) } \\
\text { D3: ANOVA test, Scheffe test }\end{array}$ \\
\hline $\begin{array}{l}\text { Sharma and Dyer } \\
\text { (2009) }\end{array}$ & $\begin{array}{l}\text { economic, } \\
\text { socio-cultural, } \\
\text { environmental }\end{array}$ & $\begin{array}{l}\text { seaside resort, } \\
\text { Queensland, } \\
\text { Australia }\end{array}$ & $\begin{array}{l}\text { D1: residents } \\
\text { D2: self-administered questionnaires (Likert } \\
\text { scale) } \\
\text { D3: descriptive statistics, t-test, mean score, } \\
\quad \text { correlation analysis }\end{array}$ \\
\hline $\begin{array}{l}\text { Prayag, } \\
\text { Dookhony- } \\
\text { Ramphul and } \\
\text { Maryeven (2010) }\end{array}$ & $\begin{array}{l}\text { economic, } \\
\text { socio-cultural, } \\
\text { environmental }\end{array}$ & $\begin{array}{l}\text { small island } \\
\text { developing state }\end{array}$ & $\begin{array}{l}\text { D1: hoteliers } \\
\text { D2: self-administered questionnaires (Likert } \\
\quad \text { scale) } \\
\text { D3: factor analyses }\end{array}$ \\
\hline $\begin{array}{l}\text { Backman, Hsu } \\
\text { and Backman } \\
(2011)\end{array}$ & socio-cultural & island, Taiwan & $\begin{array}{l}\text { D1: residents } \\
\text { D2: self-administered questionnaires (Likert } \\
\quad \text { scale) } \\
\text { D3: MANOVA analysis }\end{array}$ \\
\hline $\begin{array}{l}\text { Brida, Osti and } \\
\text { Faccioli (2011) }\end{array}$ & $\begin{array}{l}\text { economic, } \\
\text { socio-cultural, } \\
\text { environmental }\end{array}$ & mountain area, Italy & $\begin{array}{l}\text { D1: residents } \\
\text { D2: self-administered questionnaires (Likert } \\
\quad \text { scale) } \\
\text { D3: cluster analysis }\end{array}$ \\
\hline $\begin{array}{l}\text { Kuvan and Akan } \\
\text { (2012) }\end{array}$ & $\begin{array}{l}\text { economic, } \\
\text { socio-cultural, } \\
\text { environmental }\end{array}$ & city, Turkey & $\begin{array}{l}\text { D1: residents, managers } \\
\text { D2: self-administered questionnaires (Likert } \\
\text { scale), interviews } \\
\text { D3: t-tests for independent samples, two-tail } \\
\quad \text { test, Levene test }\end{array}$ \\
\hline
\end{tabular}




\begin{tabular}{|c|c|c|c|}
\hline Author(s) & Tourism impacts & Application area & Data \\
\hline $\begin{array}{l}\text { Rio and Nunes } \\
\text { (2012) }\end{array}$ & $\begin{array}{l}\text { economic, } \\
\text { socio-cultural, } \\
\text { environmental }\end{array}$ & $\begin{array}{l}\text { rural region, } \\
\text { Ukraine }\end{array}$ & $\begin{array}{l}\text { D1: government, universities, tourism } \\
\text { industry, NGOs, local community, natural } \\
\text { resources administration } \\
\text { D2: Delphi questionnaires; questionnaires } \\
\text { (Likert scale) } \\
\text { D3: analysis of the variance by Kruskal-Wallis } \\
\text { test }\end{array}$ \\
\hline $\begin{array}{l}\text { Garau-Vadell, } \\
\text { Díaz-Armas and } \\
\text { Gutierrez-Taño } \\
\text { (2013) }\end{array}$ & $\begin{array}{l}\text { economic, } \\
\text { socio-cultural, } \\
\text { environmental }\end{array}$ & island, Spain & $\begin{array}{l}\text { D1: residents } \\
\text { D2: self-administered questionnaires (Likert } \\
\text { scale) } \\
\text { D3: cluster analysis, discriminant analysis, } \\
\text { ANOVA, NOVAS and frequency } \\
\text { distribution tests }\end{array}$ \\
\hline $\begin{array}{l}\text { Jaafar, Kayat, } \\
\text { Tangit and Yacob } \\
\text { (2013) }\end{array}$ & $\begin{array}{l}\text { economic, socio- } \\
\text { cultural }\end{array}$ & $\begin{array}{l}\text { national park, } \\
\text { Malaysia }\end{array}$ & $\begin{array}{l}\text { D1: residents } \\
\text { D2: face-to-face interviews (open-ended } \\
\quad \text { questions) } \\
\text { D3: qualitative analysis of the interviews }\end{array}$ \\
\hline $\begin{array}{l}\text { Presenza and } \\
\text { Sheehan (2013) }\end{array}$ & $\begin{array}{l}\text { economic, } \\
\text { socio-cultural, } \\
\text { environmental }\end{array}$ & seaside resort, Italy & $\begin{array}{l}\text { D1: residents } \\
\text { D2: self-administered questionnaires (Likert } \\
\quad \text { scale) } \\
\text { D3: K-means ipsative clustering method }\end{array}$ \\
\hline $\begin{array}{l}\text { Simão' and } \\
\text { Môsso (2013) }\end{array}$ & $\begin{array}{l}\text { economic, } \\
\text { socio-cultural, } \\
\text { environmental }\end{array}$ & island, Cape Verde & $\begin{array}{l}\text { D1: residents } \\
\text { D2: interviews (Likert scale) } \\
\text { D3: t-student test, Pearson correlation } \\
\quad \text { analysis }\end{array}$ \\
\hline $\begin{array}{l}\text { Strickland-Munro } \\
\text { and Moore (2013) }\end{array}$ & $\begin{array}{l}\text { economic, socio- } \\
\text { cultural }\end{array}$ & $\begin{array}{l}\text { national park, } \\
\text { Australia }\end{array}$ & $\begin{array}{l}\text { D1: residents, state government employees, } \\
\text { tourism operators; documents related the } \\
\text { Park } \\
\text { D2: semi-structured interviews (open-ended } \\
\text { questions) } \\
\text { D3: three-step coding method for qualitative } \\
\text { content analysis }\end{array}$ \\
\hline $\begin{array}{l}\text { Stylidis, Biran, Sit } \\
\text { and Szivas (2014) }\end{array}$ & $\begin{array}{l}\text { economic, } \\
\text { socio-cultural, } \\
\text { environmental }\end{array}$ & city, Greece & $\begin{array}{l}\text { D1: residents } \\
\text { D2: self-administered questionnaires (Likert } \\
\text { scale) } \\
\text { D3: Exploratory Factor Analysis, Confirmatory } \\
\quad \text { Factor Analysis }\end{array}$ \\
\hline $\begin{array}{l}\text { Xie, Bao and } \\
\text { Kerstetter (2014) }\end{array}$ & $\begin{array}{l}\text { economic, social, } \\
\text { environmental }\end{array}$ & $\begin{array}{l}\text { national park, } \\
\text { China }\end{array}$ & $\begin{array}{l}\text { D1: residents } \\
\text { D2: self-administered questionnaires (Likert } \\
\quad \text { scale) } \\
\text { D3: multiple-group analysis in structural } \\
\quad \text { equation modeling }\end{array}$ \\
\hline $\begin{array}{l}\text { Sinclair-Maragh, } \\
\text { Gursoy and } \\
\text { Vieregge (2015) }\end{array}$ & $\begin{array}{l}\text { economic, } \\
\text { socio-cultural, } \\
\text { environmental }\end{array}$ & rural region, Turkey & $\begin{array}{l}\text { D1: residents } \\
\text { D2: self-administered questionnaires (Likert } \\
\quad \text { scale) } \\
\text { D3: cluster analysis }\end{array}$ \\
\hline
\end{tabular}

Source: own research 
The common basis for almost all research is the social exchange theory developed by Ap (1992). The application of the social exchange theory in destination stakeholders' management "assumes that stakeholders' attitudes towards and support for tourism in their community will be influenced by their evaluations of the actual and perceived outcomes tourism has in their community" (Byrd, Bosley, \& Dronberger, 2009, p. 694).

It is evident that the economic impacts / outcomes are considered to be the most important for the destination / regional development (Sharma et al., 2008), and thus, they are able to influence the stakeholders' support of tourism policy in greatest extent (Gursoy \& Rutherford, 2004; Xie, Bao, \& Kerstetter, 2014). Nevertheless, it is possible to identify a rising interest in both the socio-cultural and environmental impacts. The authors usually examine all three tourism impacts within the framework of sustainable tourism development which has become popular in recent decades (e.g. Lankford \& Howard, 1994; Sharma \& Dyer, 2009; Kuvan \& Akan, 2012; Xie, Bao, \& Kerstetter, 2014). As Backman, Hsu, and Backman (2011) note, the social, cultural and environmental impacts of tourism have received the same attention of the researchers as the economic impacts. The research which is purely focused on social / cultural impact is an exception motivated by current situation in a destination (Teo, 1994; Besculides, Lee, \& McCormick, 2002; Sharma et al., 2008), future intention in the sphere of destination management / development (Backman, Hsu, \& Backman, 2011) or by specific research goals of the authors (Brunt \& Courtney, 1999; Haley, Snaith, \& Miller, 2005).

Byrd, Bosley, and Dronberger (2009) who made an extensive literature review of the papers published between 1990 and 2006 define four main stakeholder groups which are frequently subjects of interest of the researchers. Their findings are in compliance with the results of the performed review. The most significant stakeholders are (a) residents (Lankford \& Howard, 1994; Haralambopoulos \& Pizam, 1996; Brunt \& Courtney, 1999; Gursoy \& Rutherford, 2004; Sharma et al., 2008; Jaafar et al., 2013; Xie, Bao, \& Kerstetter, 2014), (b) tourists (Lu, Wu, \& Xiao, 2006; Byrd, Bosley, \& Dronberger, 2009), (c) regional or local government (Byrd, Bosley, \& Dronberger, 2009), and (d) entrepreneurs (Lu, Wu, \& Xiao, 2006; Byrd, Bosley, \& Dronberger, 2009; Prayag, Dookhony-Ramphul, \& Maryeven, 2010).

The literature review suggests that residents should be considered the main actors of the tourism development process. As Gursoy and Rutherford (2004, p. 495) explained, this group of stakeholder had the power to influence the success and sustainability of any development and thus, "understanding the antecedents of support by local residents towards tourism development is crucial for local governments, policy-makers, and businesses". On the other hand, this stakeholder group is heavily influenced by tourism and its impacts at the same time (Gursoy, Jurowski, \& Uysal, 2002). This mutual strong links between this stakeholder group and tourism impacts on economic, social and environmental development has become a matter of interest of many researchers.

The researchers almost exclusively use self-administered questionnaires with the "Likert-Scale-type" questions as a data gathering tool. Some of them prefer face-to-face semistructured interviews with stakeholders to be able to obtain detail or contextual information (e.g. Brunt \& Courtney, 1999; Bruyere, Beh, \& Lelengula, 2009; Jaafar et. al, 2013). 
Rio and Nunes (2012) combine the Delphi survey based on open-ended questions and scoring with the survey using questionnaires with the "Likert-Scale-type" questions.

The data analysis is carried out by using different methods to meet the research aim. The methods can be classified into two general groups:

- Quantitatively oriented methods - different statistical tests such as ANOVA test, Scheffe test, t-test, two-tail test, Leven test, the goodness-of-fit index (GFI), KruskalWallis test (e.g., Gursoy \& Rutherford, 2004; Byrd, Bosley, \& Dronberger, 2009; Kuvan \& Akan, 2012; Rio \& Nunes, 2012), cluster analysis (e.g., Sharma et al., 2008; Brida, Osti, \& Faccioli, 2011; Sinclair-Maragh, Gursoy, \& Vieregge, 2015), or Exploratory and Confirmatory Factor Analysis (e.g., Dyer et al., 2007; Stylidis et al., 2014);

- Qualitatively oriented methods - content analysis of the interviews or government information \& documents (Bruyere, Beh, \& Lelengula, 2009; Strickland-Munro, \& Moore, 2013; Jaafar et. al, 2013).

\section{Conclusion}

This paper deals with the topic of tourism impact on a tourism destination. It summarizes current research approaches to the classification and assessment of tourism impacts and pays special attention to stakeholders' perception of tourism impacts within the context of implementation of tourism policy and managing tourism development.

It is evident that the examination of tourism impacts has received systematical attention since 1970s / 1980s. Although the research has been predominantly focused on economic impacts as the most important effects of tourism on the development of any destination, the attention devoted to socio-cultural and environmental effects has been rising in recent decades, too. The concept of sustainable tourism development has made this effort more intense. Nowadays, the authors generally reach an agreement on tourism impacts in all three main spheres.

The common effort to apply principles of sustainable destination management has caused a rising interest in the application of stakeholders' management theory in travel \& tourism sector. Four stakeholder groups are most frequently used as subjects of researcher interest - residents, followed by visitors, regional or local government and entrepreneurs in tourism services. The researchers has been trying to expose stakeholders' perception of tourism impacts in hope of better understanding and propose such a management style which will be in compliance with their desires and needs, and beneficial for all important destination stakeholders.

After completing the literature review, it was possible to identify three main factors which limit the research effort:

- Data availability: The researchers are almost exclusively dependent on stakeholders' willingness to provide data. As Xie, Bao, and Kerstetter (2012) imply, it is not easy to convince representative sample of the respondents to participate in research and 
provide researchers with reliable data in the pre-defined structure and requested quality.

- Data gathering method: Researchers using self-administered questionnaires do not have a chance to clarify the questions (scale) to respondents afterwards. For example, Sinclair-Maragh, Gursoy, and Vieregge (2015) point out that they have some doubts about respondents' ability to fully understand the scale and validity of their answers. Moreover, "Likert-Scale-type" questions limit respondents' answers to the pre-defined scale and sometimes tempt them to use central - "dull" - answers which are difficult for sophisticated interpretation.

- Results comparability: Although it is possible to find some tourism impact attitude scales (e.g., Lankford \& Howard, 1994; Choi \& Sirakaya, 2006), there is a lack of widely-accepted methodology for examination and measurement of tourism impacts. Almost all authors use own methodology - mostly based on individual previous research or integrative literature review - and different scope of the scale, and thus, it is not easy to compare their results. In addition, the research has a form of a case studies focused on a particular area. Therefore, the results might be affected by many tangible and intangible factors connected with the examined destination (area). That is why many authors (e.g., Prayag, Dookhony-Ramphul, \& Maryeven, 2010) suggest an extension of the research.

Some implications for future research can be determined as a result of this comprehensive summary. The theoretical framework should be defined by the concept of regional development via tourism sector and stakeholders' management theory together with its application in tourism sector. The concept of sustainable tourism development / management should be taken into account, too. The research should cover more than one application area to be able to compare and generalize the results. It should concentrate on four most important groups of destination stakeholders when examining their perception of tourism impacts as a determinant of their support to tourism development / destination management. The researchers should prefer face-to-face interviews to be able to explain the purpose of the research, all questions and give the respondents a chance to extend their comments.

It should be advantageous to enrich conventional data processing methods with the application of some method from different managerial sphere. Some good examples can be found in the research of $\mathrm{Lu}, \mathrm{Wu}$, and Xiao (2006) who use a simple fuzzy approach for examining stakeholders' perception of the hierarchically sorted attributes related to tourism impacts. Such combination of fuzzy approach and multi-criteria methods seems to be relatively underestimated research area in this field despite its strong information value for policy makers / destination managers, and thus, it may be an attractive topic for any future research. 


\section{References}

Aas, Ch., Ladkin, A., \& Fletcher, J. (2005). Stakeholder Collaboration and Heritage Management. Annals of Tourism Research, 32(1), 28-48. DOI: 10.1016/j.annals.2004.04.005.

Alavi, J., \& Yasin, M. M. (2000). A Systematic Approach to Tourism Policy. Journal of Business Research, 48(2), 147-157. DOI: 10.1016/S0148-2963(98)00096-4.

Andereck, K. L., Valentine, K. M., Knopf, R. C., \& Vogt, Ch. A. (2005). Residents' Perceptions of Community Tourism Impacts. Annals of Tourism Research, 32(4), 1056-1076. DOI: 10.1016/j. annals.2005.03.001.

Ap, J. (1992). Residents' Perceptions on Tourism Impacts. Annals of Tourism Research, 19(4), 665690. DOI: 10.1016/0160-7383(92)90060-3.

Backman, K. F., Hsu, C. H., \& Backman, S. J. (2011). Tao Residents' Perceptions of Social and Cultural Impacts of Tourism in Lan-Yu, Taiwan. Event management, 15(2), 121-136.

Besculides, A., Lee, M. A., \& McCormick, P. J. (2002). Residents' Perceptions of the Cultural Benefits of Tourism. Annals of Tourism Research, 29(2), 303-319. DOI: 10.1016/S0160-7383(01)000664.

Brida G., J., Osti, L., \& Faccioli, M. (2011). Residents' Perception and Attitudes towards Tourism Impacts: A Case Study of the Small Rural Community of Folgaria (Trentino-Italy). Benchmarking: An International Journal, 18(3), 359-385. DOI: 10.1108/14635771111137769.

Brunt, P., \& Courtney, P. (1999). Host Perceptions of Sociocultural Impacts. Annals of tourism Research, 26(3), 493-515. DOI: 10.1016/S0160-7383(99)00003-1.

Bruyere, B. L., Beh, A. W., \& Lelengula, G. (2009). Differences in Perceptions of Communication, Tourism Benefits, and Management Issues in a Protected Area of Rural Kenya. Environmental Management, 43(1), 49-59. DOI: 10.1007/s00267-008-9190-7.

Bryson, J. M. (1995). Strategic Planning for Public and Nonprofit Organizations. San Francisco, CA: Jossey-Bass.

Bryson, J. M. (2004). What to do when Stakeholders matter: Stakeholder Identification and Analysis Techniques. Public Management Review, 6(1), 21-53. DOI: 10.1080/14719030410001675722.

Buhalis, D. (2000). Marketing the Competitive Destination of the Future. Tourism Management, 21(1), 97-116. DOI: 10.1016/S0261-5177(99)00095-3.

Byrd, E. T., Bosley, H. E., \& Dronberger, M. G. (2009). Comparisons of Stakeholder Perceptions of Tourism Impacts in Rural Eastern North Carolina. Tourism Management, 30(5), 693-703. DOI: 10.1016/j.tourman.2008.10.021.

Byrd, E. T., Cardénas, D. A., \& Greenwood, J. B. (2008). Factors of Stakeholder Understanding of Tourism: The Case of Eastern North Carolina. Tourism and Hospitality Research, 8(3), 192-204. DOI: $10.1057 /$ thr.2008.21.

Byrd, E. T., \& Gustke, L. D. (2004). Identifying Tourism Stakeholder Groups Based on Support for Sustainable Tourism Development and Participation in Tourism Activities. In F. D. Pineda, \& C. A. Brebbia (Eds.), Sustainable Tourism: The Sustainable World (pp. 97-108). London: WIT Press.

Caroll, A. B. (1993). Business and Society: Ethics and Stakeholder Management. Cincinnati: SouthWestern Publishing.

Clarkson, M. (1995). A Stakeholder Framework for analyzing and evaluating Corporate Social Performance, Academy of Management Review, 20(1), 92- 117.

Colarič-Jakše, L. M. (2015). Connecting Social Actors in Developing Integrated Tourism Products. Journal of Universal Excellence, 4(1), 1-16.

Cooper, Ch., Fletcher, J., Fyall, A., Gilbert, D., \& Wanhill, S. (2008). Tourism: Principles and Practice. Harlow: Pearson Education. 
Dwyer, L., Forsyth, P., \& Dwyer, W. (2010). Tourism Economics and Policy. Bristol: Channel View Publications.

Dyer, P., Gursoy, D., Sharma, B., \& Carter, J. (2007). Structural Modeling of Resident Perceptions of Tourism and Associated Development on the Sunshine Coast, Australia. Tourism Management, 28(2), 409-422. DOI: 10.1016/j.tourman.2006.04.002.

Eden, C., \& Ackermann, F. (1998). Making Strategy: The Journey of Strategic Management, London: Sage Publications.

Edgell, D. L., DelMastro Allen, M., Smith, G., \& Swanson, J. R. (2008). Tourism Policy and Planning. Yesterday, Today and Tomorrow. Oxford: Elsevier.

Freeman, R. E. (1984). Strategic Management: A Stakeholder Approach. Boston: Pitman.

Friedman, A. L., \& Miles, S. (2006). Stakeholders: Theory and Practice. New York: Oxford University Press.

Garau-Vadell, J. B., Díaz-Armas, R., \& Gutierrez-Taño, D. (2014). Residents' Perceptions of Tourism Impacts on Island Destinations: A Comparative Analysis. International Journal of Tourism Research, 16(6), 578-585. DOI: 10.1002/jtr.1951.

Gibson, K. (2000). The Moral Basis of Stakeholder Theory. Journal of Business Ethics, 26(3), 245257. DOI: $10.1023 / \mathrm{A}: 1006110106408$.

Goeldner, Ch. R., \& Ritchie, J. R. B. (2012). Tourism: Principles, Practices, Philosophies. Hoboken: John Wiley and Sons.

Gray, R. H., Owen, D. L., \& Adams, C. (1996). Accounting and Accountability: Changes and Challenges in Corporate Social and Environmental Reporting. Hemel Hempstead: Prentice-Hall.

Gunn, C. A. (1994). Tourism Planning: Basics, Concepts, Cases. Washington, DC: Taylor \& Francis.

Gursoy, D., Jurowski, C., \& Uysal, M. (2002). Residents Attitudes: A Structural Modeling Approach. Annals of Tourism Research, 29(1), 79-105.

Gursoy, D., \& Rutherford, D. G. (2004). Host Attitudes Toward Tourism: An Improved Structural Model. Annals of Tourism Research, 31(3), 495-516. DOI: 10.1016/j.annals.2003.08.008.

Haley, A. J., Snaith, T., \& Miller, G. (2005). The Social Impacts of Tourism: A Case Study of Bath, UK. Annals of tourism research, 32(3), 647-668. DOI: 10.1016/j.annals.2004.10.009.

Hall, C. M. (2008). Tourism Planning: Policies, Processes and Relationships. Harlow: Prentice Hall.

Haralambopoulos, N., \& Pizam, A. (1996). Perceived Impacts of Tourism: The Case of Samos. Annals of Tourism Research, 23(3), 503-526. DOI: 10.1016/0160-7383(95)00075-5.

Choi, H. Ch., \& Sirakaya, E. (2006). Sustainability Indicators for Managing Community Tourism. Tourism Management, 27(6), 1274-1289. DOI: 10.1016/j.tourman.2005.05.018.

Jaafar, M., Kayat, K., Tangit, T. M., \& Yacob, M. F. (2013). Nature-based Rural Tourism and its Economic Benefits: A Case Study of Kinabalu National Park. Worldwide Hospitality and Tourism Themes, 5(4), 342-352. DOI: 10.1108/WHATT-03-2013-0016.

Jóhannesson, G. T. (2005). Tourism translations: Actor-Network Theory and tourism research. Tourist Studies, 5(2), 133-150. DOI: 10.1177/1468797605066924.

Johnson, G., \& Scholes, K. (2002). Exploring Corporate Strategy. Harlow, England: Pearson Education.

Kozak, M. (2004). Destination Benchmarking: Concepts, Practices and Operations. Wallingford: CABI Publishing.

Kuvan, Y., \& Akan, P. (2012). Conflict and Agreement in Stakeholder Attitudes: Residents' and Hotel Managers' Views of Tourism Impacts and Forest-related Tourism Development. Journal of Sustainable Tourism, 20(4), 571-584. DOI: 10.1080/09669582.2011.617824.

Lampe, M. (2001). Mediation as an Ethical Adjunct of Stakeholder Theory. Journal of Business Ethics, 31(2), 165-173. DOI: 10.1023/A:1010749313936. 
Lankford, S. V., \& Howard, D. R. (1994). Developing a Tourism Impact Attitude Scale. Annals of tourism research, 21(1), 121-139. DOI: 10.1016/0160-7383(94)90008-6.

Lu, X. L., Wu, C. Y., \& Xiao, G. R. (2006). Fuzzy Synthetic Evaluation on Resident's Perceptions of Tourism Impacts. Chinese Geographical Science, 16(1), 87-94. DOI: 10.1007/s11769-006-0028-z.

Mason, P. (2008). Tourism Impacts, Planning and Management. Amsterdam: Butterworth-Heinemann. Mitchell, R. K., Agle, B. R., \& Wood, D. J. (1997). Toward a Theory of Stakeholder Identification and Salience: Defining the Principle of Who and What Really Counts. The Academy of Management Review, 22(4), 853-886.

Morrison, A. M. (2013). Marketing and Managing Tourism Destinations. New York: Routledge.

Mugambi, M. D., \& Mburu, J. I. (2013). Estimation of the Tourism Benefits of Kakamega Forest, Kenya: A Travel Cost Approach. Environment and Natural Resources Research, 3(1), 62-67.

Musil, M., \& Luštický, M. (2010). Modelování jako nástroj pro efektivní ŕízení turistické destinace I (Modelling as a Tool for Effective Management of a Tourist Destination I). Czech Hospitality and Tourism Papers - Hotelnictví, lázeňství, turismus, 6(12), 104-125.

Newsome, D., Moore, S. A., \& Dowling, R. K. (2013). Natural Area Tourism: Ecology, Impacts and Management. Bristol: Channel View Publications.

Nutt, P., \& Backoff, R. (1992). Strategic Management of Public and Third Sector Organizations: A Handbook for Leaders. San Francisco, CA: Jossey-Bass.

Page, S. J. (2013). Tourism Management: An Introduction. New York: Routledge.

Paget, E., Dimanche, F., \& Mounet, J. P. (2010). A Tourism Innovation Case: An Actor-Network Approach. Annals of Tourism Research, 37(3), 828-847. DOI: 10.1016/j.annals.2010.02.004.

Pásková, M. (2014). Udržitelnost rozvoje cestovniho ruchu (Sustainable tourism). Hradec Králové, Czech Republic: Gaudeamus.

Phillips, R. (2003). Stakeholder Legitimacy. Business Ethics Quarterly, 13(1), 25-41. DOI: 10.5840/ beq20031312.

Pomucz, A. B., \& Csete, M. (2015). Sustainability Assessment of Hungarian Lakeside Tousim Development. Periodica Polytechnica Social and Management Sciences, 23(2), 121-132.

Pratt, S. (2015). The Economic Impact of Tourism in SIDS. Annals of Tourism Research, 52, 148-160. DOI: 10.1016/j.annals.2015.03.005.

Prayag, G., Dookhony-Ramphul, K., \& Maryeven, M. (2010). Hotel Development and Tourism Impacts in Mauritius: Hoteliers' Perspectives on Sustainable Tourism. Development Southern Africa, 27(5), 697-712. DOI: 10.1080/0376835X.2010.522832.

Presenza, A., \& Sheehan, L. (2013). Planning Tourism through Sporting Events. International Journal of Event and Festival Management, 4(2), 125-139. DOI: 10.1108/17582951311325890.

Presenza, A., Sheehan, L., \& Ritchie, J. R. B. (2005). Towards a Model of the Roles and Activities of Destination Management Organizations. Journal of Hospitality, Tourism and Leisure Science, $3(1), 1-16$.

Rio, D., \& Nunes, L. M. (2012). Monitoring and Evaluation Tool for Tourism Destinations. Tourism Management Perspectives, 4, 64-66.

Ritchie, J. R. B. (1984). Assessing the Impact of Hallmark Events: Conceptual and Research Issues. Journal of Travel Research, 23(1), 2-11. DOI: 10.1177/004728758402300101.

Ritchie, J. R. B., \& Crouch, G. I. (2003). The Competitive Destination: A Sustainable Tourism Perspective. Wallingford: CABI Publishing.

Savage, G. T., Nix, T. W., Whitehead, C. J., \& Blair, J. D. (1991). Strategies for Assessing and Managing Organizational Stakeholder, Academy of Management Executive 5(2), pp. 61 - 75. DOI: 10.5465/AME.1991.4274682. 
Saxena, G. (2014). Rural Tourism Partnerships and Actor Mobility. International Journal of Tourism Research, 16(5), 488-495. DOI: 10.1002/jtr.1942.

Simão, J., \& Môsso, A. (2013). Residents' Perceptions Towards Tourism Development: The Case of Sal Island. International Journal of Development Issues, 12(2), 140-157. DOI: 10.1108/IJDI-122012-0076.

Sinclair-Maragh, G., Gursoy, D., \& Vieregge, M. (2015). Residents’ Perceptions Toward Tourism Development: A Factor-cluster Approach. Journal of Destination Marketing $\mathcal{E}$ Management, 4(1), 36-45. DOI: 10.1016/j.jdmm.2014.10.001.

Sharma, K. K. (2004). Tourism and Regional Development. New Delhi: Sarup \& Sons.

Sharma, B., \& Dyer, P. (2009). Residents' Involvement in Tourism and their Perceptions of Tourism Impacts. Benchmarking: An International Journal, 16(3), 351-371. DOI: $10.1108 / 14635770910961371$.

Sharma, B., Dyer, P., Carter, J., \& Gursoy, D. (2008). Exploring Residents' Perceptions of the Social Impacts of Tourism on the Sunshine Coast, Australia. International Journal of Hospitality E Tourism Administration, 9(3), 288-311. DOI: 10.1080/15256480802096092.

Steenge, A. E., \& Van De Steeg, A. M. (2010). Tourism Multipliers for a Small Caribbean Island State; The Case of Aruba. Economic Systems Research, 22(4), 359-384. DOI: $10.1080 / 09535314.2010 .526926$.

Strickland-Munro, J., \& Moore, S. (2013). Indigenous Involvement and Benefits from Tourism in Protected Areas: A Study of Purnululu National Park and Warmun Community, Australia. Journal of Sustainable Tourism, 21(1), 26-41. DOI: 10.1080/09669582.2012.680466.

Stylidis, D., Biran, A., Sit, J., \& Szivas, E. M. (2014). Residents' Support for Tourism Development: The Role of Residents' Place Image and Perceived Tourism Impacts. Tourism Management, 45, 260-274. DOI: 10.1016/j.tourman.2014.05.006.

Teo, P. (1994). Assessing Socio-cultural Impacts: The Case of Singapore. Tourism Management, 15(2), 126-136. DOI: 10.1016/0261-5177(94)90006-X.

Vanhove, N. (2011). The Economics of Tourism Destinations. New York: Routledge.

Wagner, J. E. (1997). Estimating the Economic Impact of Tourism. Annals of Tourism Research, 24(3), 592-608. DOI: 10.1016/S0160-7383(97)00008-X.

Waligo, V. M., Clarke, J., \& Hawkins, R. (2013). Implementing Sustainable Tourism: A Multistakeholder Involvement Management Framework. Tourism Management, 36, 342-353. DOI: 10.1016/j.tourman.2012.10.008.

Wall, G., \& Mathieson, A. (2005). Tourism: Changes, Impacts and Opportunities. London: Pearson Education.

Wicks, A. C., Gilbert, D. R., Jr., \& Freeman, R. E. (1994). A feminist reinterpretation of the stakeholder concept. Business Ethics Quarterly, 4(4), 475-497. DOI: 10.2307/3857345.

Xie, H., Bao, J., \& Kerstetter, D. L. (2014). Examining the Effects of Tourism Impacts on Satisfaction with Tourism between Native and Non-native Residents. International Journal of Tourism Research, 16(3), 241-249. DOI: 10.1002/jtr.1922.

Yuksel, F., Bramwell, B., \& Yuksel, A. (1999). Stakeholder Interviews and Tourism Planning at Pamukkale, Turkey. Tourism management, 20(3), 351-360. DOI: 10.1016/S0261-5177(98)00117-4.

Zhong, L., Deng, J., Song, Z., \& Ding, P. (2011). Research on Environmental Impacts of Tourism In China: Progress and Prospect. Journal of Environmental Management, 92(11), 2972-2983. DOI: 10.1016/j.jenvman.2011.07.011.

Zhou, D., Yanagida, J. F., Chakravorty, U., \& Leung, P. (1997). Estimating Economic Impacts from Tourism. Annals of Tourism Research, 24(1), 76-89. DOI: 10.1016/S0160-7383(96)00035-7. 